\title{
Appraisal of Cell Cycle Delay and Cytotoxicity Inducing Potential of 3-epicaryoptin in Allium Cepa $\mathbf{L}$.
}

\section{Manabendu Barman, Sanjib Ray*}

Molecular Biology and Genetics Unit, Department of Zoology, The University of Burdwan, Golapbag, Purba Bardhaman-713104, West Bengal, India.

*Corresponding author.

E-mail address: sray@zoo.buruniv.ac.in; ray.sanjibray@gmail.com

\begin{abstract}
Diterpenoid 3-epicaryoptin $\left(\mathrm{C}_{26} \mathrm{H}_{36} \mathrm{O}_{9}\right)$ is abundant in leaves of Clerodendrum inerme, a traditionally used medicinal plant, having insect antifeedant activities. Here, we aim to explore its cell cycle delay and cytotoxic effects in Allium cepa root apical meristem cells. Allium cepa roots were treated with 3 -epicaryoptin $\left(100,150 \& 200 \mu \mathrm{g} \mathrm{mL}^{-1}\right.$ concentration) and colchicine $\left(200 \mu \mathrm{g} \mathrm{mL}^{-1}\right.$ concentration) for $2,4,4+16 \mathrm{~h}$ (4 h treatment followed by $16 \mathrm{~h}$ recovery) and the induced cell cycle delay and cytotoxic effects were analyzed. The highest metaphase cells frequency for 3-epicaryoptin $\left(150 \mu \mathrm{g} \mathrm{mL}^{-1}\right)$ and colchicine $\left(200 \mu \mathrm{g} \mathrm{mL} \mathrm{m}^{-1}\right)$ treated samples were found to be $66.2 \pm 0.58 \%$ and $82.35 \pm 0.74 \%$ respectively at $4 \mathrm{~h}$ treatment. Treatment of 3-epicaryoptin and colchicine increased the aberrant cells $\%$, CA, MN, c-metaphase, and PP cells. Therefore, indiscriminate use of $C$. inerme in traditional medicine should be restricted and the cell cycle delay and cytotoxicity inducing effects of 3epicaryoptin needs further exploration for its cancer chemotherapeutic applications.
\end{abstract}

Keywords: 3-epicaryoptin; Allium cepa test; metaphase arrest; chromosomal abnormalities; micronuclei; polyploidy 


\section{Introduction}

3-epicaryoptin, a clerodane diterpenoid, was first isolated and identified by Hosozawa et al. (1974a) from the leaves of Clerodendrum calamitosum Maxim (Verbenaceae) (Hosozawa et al., 1974). In the case of natural products, diterpenoids have emerged as one of the most important secondary metabolites given their distinct biological activities and drug-like properties as demonstrated by the success of taxane-type diterpenoids in preclinical studies and clinical treatments. Among the diterpenoid groups, the clerodane diterpenoids comprise a large class of natural products which have been studied more in recent years for their wide range of biological activities like anticancer, anti-inflammatory, antifeedant, etc. (Li et al., 2016). Recently we have isolated four clerodane diterpenoids: a) Clerodin, b) 15-hydroxy-14, 15-dihydroclerodin, c) 15-methoxy-14, 15-dihydroclerodin, and d) 14, 15-dihydroclerodin from leaf aqueous extract of $C$. viscosum and shown to have their pro-metaphase arresting, PP, MN, and CA inducing activities (Roy et al., 2020a; Roy et al., 2020b). Earlier the isolated compound 3-epicaryoptin from $C$. inerme had shown to possess potent insect antifeedant activity against the third instar larvae of the tobacco cutworm, Spodoptera litura F. and fourth instar nymphs and adults of the potato beetle Henosepilachna vigntioctopunctata Fab. (Coleoptera: Coccinellidae) (Govindachari et al., 1999; Hosozawa et al., 1974). In addition to insect antifeedant activity, 3-epicaryoptin reduced the growth and increased the mortality of Ostrinia nubilalis (Hubner) (European com borer) larvae (Beninger et al., 1993). It had also inhibited the development of Musca domestica and Culex quinquefasciatus larvae (Pereira and Gurudutt, 1990). Although the insect antifeedant and larvicidal potential of 3epicaryoptin has been well documented, yet there is no report available on its cytotoxic effects.

Clerodendrum inerme (L.) Gaertn. (family Lamiaceae) is a perennial shrub, widely distributed in tropical and subtropical regions of the world. The plant is used in ayurvedic 
medicine for the treatment of various diseases such as rheumatism, asthma, stomach pains, hepatitis, skin disease, tumours, etc. (Kirtikar and Basu, 1975; Muthu et al., 2006) Pharmacological studies have showed that $C$. inerme leaves have analgesic and antiinflammatory (Amirtharaj et al., 2010; Khanam et al., 2014), antidiabetic (Rajeev et al., 2012, antipyretic (Thirumal et al., 2013), mosquito larvicidal (Kalyanasundaram and Das, 1985, hepatoprotective (Chakraborthy and Verma, 2013), antifungal (Sharma and Verma, 1991), antimicrobial (Anandhi and Ushadevi, 2013; George and Pandalai, 1949), antiviral (Mehdi et al., 1997) and anticancer (Manoharan et al. 2006; Chouhan et al., 2018; Kalavathi et al., 2016) activities. Phytochemical investigation of different parts of the $C$. inerme revealed the presence of glycosides, anthraquinones, proteins, phenolics, flavonoids, saponins, tannins, iridoids, diterpenes, triterpenes, sterols, steroids, carbohydrates, fixed oils, volatile oils, lignin, etc (Prasad et al., 2012; Tanu et al., 2011). In our previous study, we have reported colchicine like metaphase (c-metaphase), and cell cycle delay inducing effects of the leaf aqueous extract of $C$. inerme in onion root tip cells (Barman et al., 2020). However, the bioactive compounds responsible for these activities are not determined. Recently we have standardized the liquid-liquid fractionation-based isolation and purification of compound 3epicaryoptin from leaf aqueous extract of $C$. inerme (Ray et al., 2019), but its cytotoxic effects yet to study. Therefore, the present study designed to investigate its cell cycle delay and cytotoxicity inducing effects on A. cepa root apical meristem cells in terms of MI alteration, CA, specifically c-metaphase, $\mathrm{MN}$, and PP induction.

Allium cepa L. is one of the most established plant bioassays for the cytotoxicological assessment due to its kinetic proliferation properties, large chromosomes and low chromosome number $(2 n=16)$, easily observed with a light microscope, as validated by the UNEP and the IPCS (Cabrera and Rodriguez, 1999; Gomes et al., 2013). Allium cepa test system provides an important information about the possible mechanisms of action of an 
agents on the genetic material (such as clastogenic or aneugenic effects) and has a strong correlation with mammalian/cell culture systems and therefore several microtubule targeting chemotherapeutic drug likes paclitaxel, vincristine, vinblastine, podophyllotoxin, has also been studied in A. cepa model for monitoring their cytogenotoxicity (Leme and MarinMorales, 2009; Cragg et al., 1996; Bonfoco et al., 1995; Sehgal et al., 2006). The use of $A$. сера as a test system was first investigated by Levan demonstrating disturbances in the mitotic spindle apparatus due to the use of colchicine (Levan, 1938). Studies have found that colchicine treatment causes root growth inhibition and swelling effects, increase the frequency of metaphase cells with haphazardly arranged condensed chromosomes by inhibiting mitotic spindle organization. As a result of these, chromatids fail to move to the opposite poles and eventually become enclosed in a new nuclear membrane and proceed into interphase as a doubled chromosomes number of PP cells (Hague and Jones 1987; Ray et al. 2013). Treatment of colchicine in A. cepa could also induce an increased frequency of CA and MN cells (Kundu \& Ray 2016). In this study, colchicine was used as a standard cytotoxic agent and its effects were compared with the 3-epicaryoptin induced cytotoxic effects in Allium cepa root tip cells.

\section{Materials and methods}

\subsection{Chemicals}

Glacial acetic acid, orcein, and methanol were purchased from Merck Ltd. Mumbai, India. Colchicine was obtained from Himedia Laboratories Pvt. Ltd. Mumbai, India. 3-epicaryoptin was extracted from $C$. inerme leaf aqueous extract (Ray Sanjib, 2019). The other chemicals were purchased from reputed manufacturers.

\subsection{Effects of 3-epicaryoptin on Allium cepa}


Allium cepa L. root apical meristem cells were used as a plant model. 3-epicaryoptin and colchicine induced root growth inhibitory effects, cell cycle kinetics, CA, MN, and PP were analyzed.

\subsection{Root growth retardation and swelling effects}

The similar sized A. cepa bulbs were purchased from a local vegetable store at Golapbag, Burdwan, and allowed for root sprouting as described earlier (Barman et al., 2020; Kundu and Ray, 2017; Ray et al., 2013). For root growth inhibition analysis, the sprouting roots were exposed continuously with the different concentrations of 3 -epicaryoptin $(12.5,25,50,100$, $\left.200 \mu \mathrm{g} \mathrm{mL}{ }^{-1}\right)$ and colchicine $\left(200 \mu \mathrm{g} \mathrm{mL}^{-1}\right)$ for 24,48 and $72 \mathrm{~h}$. The roots length was measured and the root growth inhibition percentage and the $\mathrm{EC}_{50}$ value were determined at 24, 48 and 72 h. 3-epicaryoptin $\left(100,150\right.$ and $\left.200 \mu \mathrm{g} \mathrm{mL}{ }^{-1}\right)$ and standard colchicine $(200 \mu \mathrm{g}$ $\mathrm{mL}^{-1}$ ) induced morphometric root tip swelling effects were also measured after $4 \mathrm{~h}$ treatment followed by $16 \mathrm{~h}$ recovery in water.

\subsection{Study of cell cycle kinetics and chromosomal aberrations}

To determine the cell cycle delay-inducing effects of 3-epicaryoptin, the MI, and dividing cell percentage at different phases were analyzed in $A$. cepa root tip cells and for the cytotoxic effects, the CA were analyzed. The onion roots (about $1.5-2 \mathrm{~cm}$ ) were exposed with the different concentrations $\left(100,150\right.$, and $\left.200 \mu \mathrm{g} \mathrm{mL}^{-1}\right)$ of 3-epicaryoptin for 2,4 , and $4 \mathrm{~h}$ and then allowed for $16 \mathrm{~h}$ recovery in water. The different cytotoxic effects were compared with the standard spindle poison, colchicine $\left(200 \mu \mathrm{g} \mathrm{mL}^{-1}\right)$. In the case of control groups, the onion roots were maintained in distilled water. For root tip squash preparation, the control and treated onion root tips were fixed in aceto-methanol 3(methanol): 1(acetic acid) for $24 \mathrm{~h}$, then hydrolysed in $1 \mathrm{~N} \mathrm{HCl}$ at $60 \square \mathrm{C}$ for 10 minutes, stained with aceto-orcein (2\%) and finally squashed in $45 \%$ acetic acid (Chaudhuri and Ray, 2015). The squashed root tips were 
observed in a bright field light microscope at 400X magnification and the prophase, metaphase, anaphase, telophase cell percentage as well as the MI, and CA were scored.

\subsection{Scoring and statistical analysis}

Data obtained on MI, (MI $(\%)=$ Number of dividing cells/Total number of cells scored X 100), cells percentage at different phase (prophase, metaphase, anaphase and telophase), CA, $\mathrm{MN}$ and PP cell frequencies were analyzed by using $2 \times 2$ contingency $\chi 2$ test and the $\mathrm{IC}_{50}$ value for the root growth retardation was calculated with probit analysis in SPSS Version 20. Differences between control and treated groups were considered as significant at $p \leq 0.05$ or 0.01 or 0.001 . All the data were expressed as mean \pm SEM (standard error of mean). Correlations among dividing phase and among different mitotic abnormalities were calculated using Pearson's bivariate correlations and analyses were done using PAST version 4.05.

\section{RESULTS}

\subsection{Root growth retardation and swelling effects}

Treatment of 3-epicaryoptin causes concentration-dependent statistically significant root growth retardation effects in A. cepa root apical meristem cells (Figure 1). The maximum root growth retardation $(89.77 \%, p<0.001)$ effect of 3-epicaryoptin treatment was at $200 \mu \mathrm{g}$ $\mathrm{mL}^{-1}$ concentration at $72 \mathrm{~h}$. The standard colchicine $\left(200 \mu \mathrm{g} \mathrm{mL} \mathrm{L}^{-1}\right)$ induced the highest root growth retardation percentage $(92.08 \%, p<0.001)$ at $72 \mathrm{~h}$. The $\mathrm{IC}_{50}$ values were $68.38,70.50$ and $63.96 \mu \mathrm{g} \mathrm{mL}^{-1}$ respectively at 24,48 , and $72 \mathrm{~h}$ of 3 -epicaryoptin treatment. The root tip swelling phenomenon was also observed in 3-epicaryoptin $\left(100,150\right.$, and $\left.200 \mu \mathrm{g} \mathrm{mL}^{-1}\right)$ and colchicine $\left(200 \mu \mathrm{g} \mathrm{mL}^{-1}\right)$ treated samples after $4 \mathrm{~h}$ treatment followed by $16 \mathrm{~h}$ water 
recovery. A comparatively better root tip swelling effect was observed at a concentration of $200 \mu \mathrm{g} \mathrm{mL}^{-1}$ of 3-epicaryoptin than colchicine treatments (Figure 1).
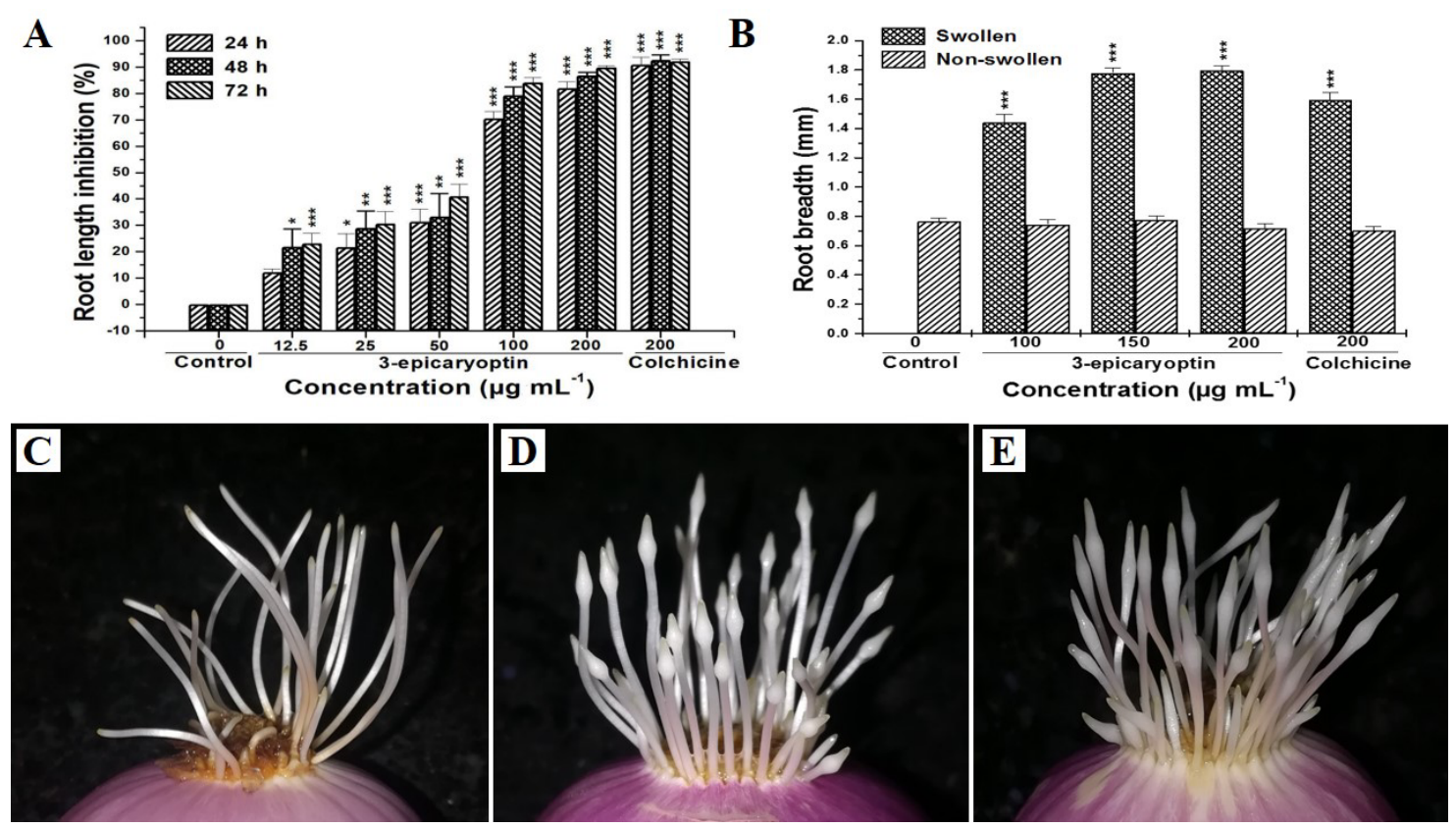

Figure 1. The effects of 3-epicaryoptin and colchicine in the A. cepa root length inhibition \% after 24,48 , and $72 \mathrm{~h}$ continuous treatment (A), and the root tip swelling effects at $16 \mathrm{~h}$ water recovery after $4 \mathrm{~h}$ treatment (B-E). (B) Measurement the diameter of the $A$. cepa root tips, (C) Control, (D) $200 \mu \mathrm{g} \mathrm{mL}^{-1}$ concentration of 3-epicaryoptin and (E) $200 \mu \mathrm{g} \mathrm{mL}^{-1}$ concentration of colchicine induced $A$. cepa root tip swelling effects.

\subsection{Mitotic index and dividing cells percentage}

The effects of 3-epicaryoptin and colchicine on the MI\% and dividing phases in A. cepa root apical meristem cells as presented in Table 1. Data indicate that 3-epicaryoptin (100, 150, and $\left.200 \mu \mathrm{g} \mathrm{mL}^{-1}\right)$ and colchicine $\left(200 \mu \mathrm{g} \mathrm{mL}^{-1}\right)$ treatment causes an increase in $\mathrm{MI} \%(p<0.001)$ at 2 and $4 \mathrm{~h}$ treated onion root tip cells. However, in the case of $16 \mathrm{~h}$ water recovery treatment, a dose-dependent decrease in MI\% was observed as compared to the untreated controls. Here, 3-epicaryoptin induced the highest MI\% at $150 \mu \mathrm{g} \mathrm{mL}^{-1}(12.29 \%)$ followed by $200 \mu \mathrm{g} \mathrm{mL}^{-1}(11.97 \%)$ at $4 \mathrm{~h}$, whereas at16 h recovery, it was decreased to $4.90 \%(p<0.01)$ and $3.33 \%(p<0.01)$ at the respective concentrations of 150 and $200 \mu \mathrm{g} \mathrm{mL}^{-1}$. In the case of 
$200 \mu \mathrm{g} \mathrm{mL}{ }^{-1}$ colchicine treatment, a statistically significant increase in MI \% $(13.18 \%, p<$ $0.001)$ was also observed at $4 \mathrm{~h}$ and again decreased $(3.22 \%, p<0.01)$ at $16 \mathrm{~h}$ recovery samples. Study of cell cycle kinetic revealed that 3-epicaryoptin $\left(150\right.$ and $\left.200 \mu \mathrm{g} \mathrm{mL}^{-1}\right)$ continuous treatment for $4 \mathrm{~h}$ causes a significant decrease in prophase $\%(23.22 \%$ and $24.49 \%)$ and increase in metaphase $\%(66.2 \%$ and $63.31 \%)$ when compared to control (28.84\%). The standard colchicine $\left(200 \mu \mathrm{g} \mathrm{mL}^{-1}\right)$ at $4 \mathrm{~h}$ also decreased prophase $(11.3 \%)$ and increased $(82.35 \%)$ the metaphase cells percentage. Both 3-epicaryoptin and colchicine treatments increased the prophase-metaphase cumulative frequency (PMCF) and the anaphase-telophase cumulative frequency (ATCF) significantly decreased (Figure 2). However, both PMCF and ATCF were always significantly higher in case of colchicinetreated samples. The increasing tendency of PMCF was observed at $4 \mathrm{~h}$ and scored as $71.43 \pm 0.59 \%, 83.03 \pm 0.59 \%$, and $89.43 \pm 0.87 \%, 87.81 \pm 0.26 \%$ respectively for $0,100,150$ and $200 \mu \mathrm{g} \mathrm{mL} \mathrm{g}^{-1}$ of 3-epicaryoptin and $93.66 \pm 1.35 \%$ for $200 \mu \mathrm{g} \mathrm{mL} \mathrm{m}^{-1}$ of colchicine treatments. On the other hand, at $4 \mathrm{~h}$ treatment, decreasing tendency of ATCFs were scored as $28.78 \pm 0.78,16.95 \pm 0.59,10.55 \pm 0.87$ and $12.17 \pm 0.26 \%$ respectively for $0,100,150$ and $200 \mu \mathrm{g} \mathrm{mL}^{-1}$ of 3 -epicaryoptin and $6.28 \pm 0.73 \%$ for $200 \mu \mathrm{g} \mathrm{mL}^{-1}$ of colchicine.

Table 1. Influence of 3-epicaryoptin and colchicine on MI and percentages of the different cell division phases of $A$. Cepa root apical meristem cells.

\begin{tabular}{|c|c|c|c|c|c|c|c|c|}
\hline $\mathrm{H}$ & $\begin{array}{l}\text { Con. } \\
\left(\mathrm{mg} / \mathrm{mL}^{-1}\right)\end{array}$ & $\mathrm{TC}$ & TDC & MI (\%) & Pro $(\%)$ & Meta (\%) & Ana $(\%)$ & Telo (\%) \\
\hline \multirow[t]{5}{*}{2} & 0 & 1731 & 88 & $5.1 \pm 0.40$ & $44.62 \pm 3.38$ & $26.65 \pm 3.27$ & $15.48 \pm 1.60$ & $13.22 \pm 2.92$ \\
\hline & 100 & 2381 & 176 & $7.41 \pm 0.44^{* *}$ & $38.29 \pm 2.75$ & $35.77 \pm 0.84$ & $13.97 \pm 1.17$ & $11.94 \pm 2.41$ \\
\hline & 150 & 1588 & 175 & $11.04 \pm 0.80 * * *$ & $36.96 \pm 0.41$ & $52.3 \pm 0.91 * *$ & $5.98 \pm 0.48^{*}$ & $4.72 \pm 0.11^{*}$ \\
\hline & 200 & 1967 & 167 & $8.48 \pm 0.57 * * *$ & $33.25 \pm 0.75$ & $44.61 \pm 0.74$ & $14 \pm 0.43$ & $8.11 \pm 0.46$ \\
\hline & $200^{@}$ & 2364 & 299 & $12.64 \pm 0.34 * * *$ & $12.77 \pm 0.41 * * *$ & $78.59 \pm 0.92 * * *$ & $7.29 \pm 0.52 *$ & $3.51 \pm 0.41 * * *$ \\
\hline \multirow[t]{5}{*}{4} & 0 & 2044 & 120 & $5.88 \pm 0.77$ & $42.58 \pm 0.16$ & $28.84 \pm 0.43$ & $13.67 \pm 1.48$ & $15.1 \pm 0.71$ \\
\hline & 100 & 2403 & 194 & $8.07 \pm 0.42^{* *}$ & $30.05 \pm 0.78$ & $51.92 \pm 0.49 * *$ & $10.45 \pm 0.27$ & $6.5 \pm 0.32 *$ \\
\hline & 150 & 2196 & 270 & $12.29 \pm 0.34 * * *$ & $23.22 \pm 0.36 * *$ & $66.2 \pm 0.58$ **** & $4.29 \pm 0.47 * *$ & $6.26 \pm 0.46^{*}$ \\
\hline & 200 & 2124 & 254 & $11.97 \pm 0.34 * * *$ & $24.49 \pm 0.16^{*}$ & $63.31 \pm 0.32 * * *$ & $4.83 \pm 0.19^{* *}$ & $7.33 \pm 0.14^{*}$ \\
\hline & $200^{@}$ & 2280 & 301 & $13.18 \pm 0.23 * * *$ & $11.3 \pm 0.60 * * *$ & $82.35 \pm 0.74 * * *$ & $4.41 \pm 0.38^{* * *}$ & $6.28 \pm 0.73^{* * * *}$ \\
\hline \multirow[t]{5}{*}{$16^{\mathrm{R}}$} & 0 & 2435 & 124 & $5.11 \pm 0.32$ & $34.21 \pm 0.49$ & $31.14 \pm 1.25$ & $15.08 \pm 1.19$ & $19.54 \pm 0.23$ \\
\hline & 100 & 1889 & 104 & $5.51 \pm 0.22$ & $29.97 \pm 0.72$ & $54.37 \pm 0.90^{*}$ & $7.69 \pm 0.32$ & $7.94 \pm 0.49 *$ \\
\hline & 150 & 2227 & 109 & $4.90 \pm 0.25$ & $39.63 \pm 0.36$ & $47.03 \pm 0.77$ & $2.39 \pm 0.47 * * *$ & $10.92 \pm 0.45$ \\
\hline & 200 & 2225 & 74 & $3.33 \pm 0.21^{* *}$ & $39.94 \pm 0.5$ & $43.11 \pm 0.51$ & $6.17 \pm 0.82$ & $10.75 \pm 0.07$ \\
\hline & $200^{@}$ & 2433 & 79 & $3.22 \pm 0.12 * *$ & $18.55 \pm 0.82$ & $41.44 \pm 0.72$ & $8.39 \pm 0.66$ & $11.76 \pm 0.89$ \\
\hline
\end{tabular}


*Significant at $p<0.05 . * *$ Significant at $p<0.01 . * * *$ Significant at $p<0.001$ as compared to their respective control with $2 \times 2$ contingency $\chi 2$ test with respective $\mathrm{d} f=1$. TC: total cells; TDC: total dividing cells; MI: mitotic index. R; Recovery $(4 \mathrm{~h}$ treatment followed by recovery).

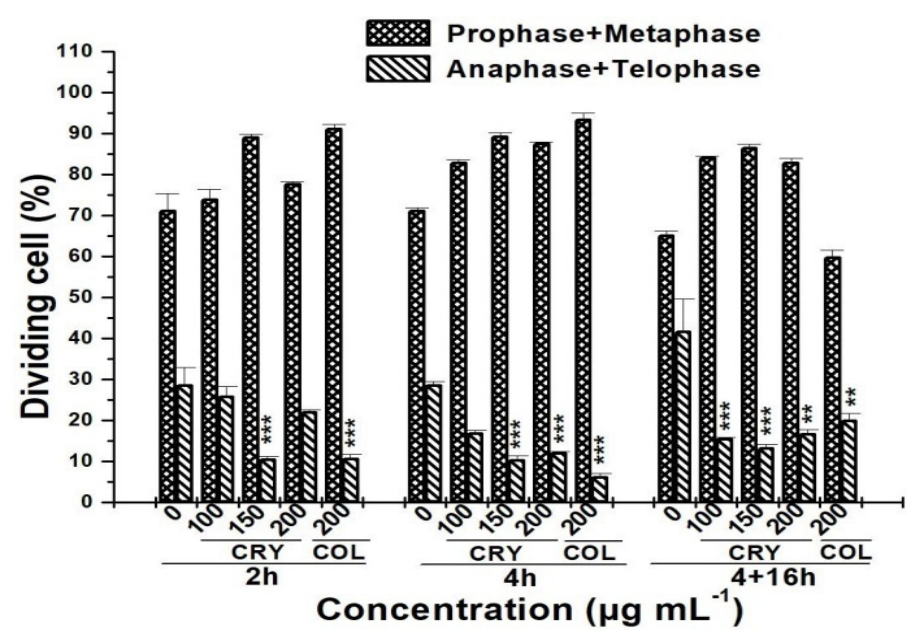

Figure 2: Influence of 3-epicaryoptin $\left(100,150,200 \mu \mathrm{g} \mathrm{mL}^{-1}\right)$ and colchicine $\left(200 \mu \mathrm{g} \mathrm{mL}^{-1}\right)$ on the 'prophase-metaphase' and 'anaphase-telophase' cumulative frequencies in A. серa root tip cells. $*$ Significant at $p<0.05, * * p<0.01$ and $* * * p<0.001$ with $2 \times 2$ contingency $\chi 2$ analysis compared to respective control at $d f=1$. Con: Control.

\subsection{Chromosomal abnormalities}

3-epicaryoptin induced different types CA (anaphase bridge, C-metaphase, vagrant, laggards and sticky chromosome, multipolar anaphase-telophase) in A. cepa root meristem cells which are comparable to colchicine effects (Table $2 \&$ Figure 3$)$. The 3 -epicaryoptin (100, 150, $\left.200 \mu \mathrm{g} \mathrm{mL}^{-1}\right)$ and colchicine $\left(200 \mu \mathrm{g} \mathrm{mL}^{-1}\right)$ induced statistically significant increased CAs. 150 $\mu \mathrm{g} \mathrm{mL} \mathrm{L}^{-1}$ of 3-epicaryoptin treatment showed significant increase the total CAs\% $(8.79 \%$, $7.8 \%$ and $30.46 \%)$ as compared to standard colchicine (13.48\%, $15.91 \%$ and $33.48 \%$ ) respectively at $2 \mathrm{~h}(p<0.001), 4 \mathrm{~h}(p<0.001)$, and $16 \mathrm{~h}$ water recovery treatment $(p<0.001)$. The most visible CAs induced by 3-epicaryoptin was c-metaphase. The mean percentages of c-metaphase were $29.61 \pm 0.81 \%, 51.56 \pm 0.57 \%$ and $41.04 \pm 0.64 \%$ at $2 \mathrm{~h}(p<0.001)$ and 
$40.95 \pm 0.87 \%, 63.39 \pm 0.51 \%$ and $60.43 \pm 0.57 \%$ at $4 \mathrm{~h}(p<0.001)$ for the respective concentration of 100,150 , and $200 \mu \mathrm{g} \mathrm{mL}^{-1}$ of 3-epicaryoptin, whereas, the negative control showed $1.01 \pm 0.50 \%$ and $0.45 \pm 0.45 \%$ of c-metaphase cells at the respective fixative hours. While $200 \mu \mathrm{g} \mathrm{mL}^{-1}$ colchicine showed the highest c-metaphase frequency $(72.65 \pm 0.11 \%$ and $77.24 \pm 0.10 \%)$ at both $2 \mathrm{~h}(p<0.001)$ and $4 \mathrm{~h}(p<0.001)$ treated samples (Table 2). 3epicaryoptin treatment also increased the frequency of vagrant chromosomes. $150 \mu \mathrm{g} \mathrm{mL}^{-1}$ of 3-epicaryoptin treatment was found to be $13.89 \pm 0.21 \%(p<0.01), 13.64 \pm 0.34 \%(p<0.01)$, and $15.09 \pm 0.49 \%(p<0.001)$ of vagrant chromosome after $2 \mathrm{~h}, 4 \mathrm{~h}$, and $4 \mathrm{~h}$ treatment followed by $16 \mathrm{~h}$ recovery in water. Colchicine $\left(200 \mu \mathrm{g} \mathrm{mL}^{-1}\right)$ induced the highest vagrant chromosome percentage $(11.53 \pm 0.03 \%)$ at $4 \mathrm{~h}$ after treatment. A significant frequency $(p<0.05)$ of sticky chromosome was also observed at $150 \mu \mathrm{g} \mathrm{mL}^{-1}(12.13 \pm 0.54 \%)$ and $200 \mu \mathrm{g} \mathrm{mL}^{-1}(11.27 \pm 0.19$ $\%)$ of 3-epicaryoptin and $200 \mu \mathrm{g} \mathrm{mL}^{-1}(15.15 \pm 0.29 \%)$ of colchicine treatment after $4 \mathrm{~h}$. Besides the above abnormalities, 3-epicaryoptin and colchicine could increase the frequency of anaphase bridge, lagging chromosome, polar deviation and multipolar anaphase-telophase. Though the frequency was not statistically significant as compared to the control group (Table 2 \& Figure 3).

Table 2. Effects of 3-epicaryoptin and colchicine on the frequency of $\mathrm{CA}$ in A. cepa root apical meristem cells.

\begin{tabular}{|c|c|c|c|c|c|c|c|c|c|c|c|}
\hline Hours & $\begin{array}{l}\text { Conc. } \\
(\mathrm{mg} / \mathrm{m} \\
\text { l) }\end{array}$ & TC & TDC & $\begin{array}{l}\text { \% of Aberrant } \\
\text { cell }\end{array}$ & $\begin{array}{l}\text { Ana- } \\
\text { Bridge (\%) }\end{array}$ & C-meta (\%) & Vagrant (\%) & Cr Sti (\%) & $\begin{array}{l}\text { Lagging } \\
\operatorname{cr}(\%)\end{array}$ & $\begin{array}{l}\text { Polar } \\
\text { deviation } \\
(\%)\end{array}$ & $\begin{array}{l}\text { Multipolar Ana } \\
\text { Telo }(\%)\end{array}$ \\
\hline \multirow[t]{5}{*}{2} & 0 & 1245 & 66 & $0.34 \pm 0.01$ & $1.01 \pm 0.5$ & $1.01 \pm 0.50$ & $0.54 \pm 0.54$ & $0.46 \pm 0.46$ & $0.95 \pm 0.47$ & 0 & 0 \\
\hline & 100 & 1160 & 78 & $3.53 \pm 0.36^{* * * *}$ & $7.66 \pm 0.15$ & $29.61 \pm 0.81^{* * * *}$ & $10.63 \pm 0.29$ & $8.04 \pm 0.48$ & $8.59 \pm 0.37$ & $3.08 \pm 0.67$ & $3.4 \pm 0.27$ \\
\hline & 150 & 1175 & 132 & $8.79 \pm 0.01 * * *$ & $8.28 \pm 0.62$ & $51.56 \pm 0.57^{* * *}$ & $13.89 \pm 0.21 * *$ & $10.25 \pm 0.33$ & $4.23 \pm 0.35$ & $1.37 \pm 0.24$ & $3.25 \pm 0.36$ \\
\hline & 200 & 1356 & 114 & $5.25 \pm 0.40 * * *$ & $7.08 \pm 0.0 .34$ & $41.04 \pm 0.64 * * *$ & $9.85 \pm 0.56$ & $9.16 \pm 0.0 .48$ & $4.91 \pm 0.25$ & $0.78 \pm 0.43$ & $4.91 \pm 0.25$ \\
\hline & 200@ & 1453 & 185 & $13.48 \pm 0.26^{* * * *}$ & $4.85 \pm 0.02$ & $72.65 \pm 0.11^{\text {**** }}$ & $9.70 \pm 0.04$ & $11.68 \pm 0.30^{*}$ & $1.25 \pm 0.17$ & $0.53 \pm 0.00$ & $1.61 \pm 0.00$ \\
\hline 4 & 0 & 1287 & 71 & $0.25 \pm 0.02$ & $0.88 \pm 0.44$ & $0.45 \pm 0.45$ & $0.97 \pm 0.48$ & $0.52 \pm 0.52$ & $0.88 \pm 0.44$ & $0.52 \pm 0.52$ & 0 \\
\hline
\end{tabular}


bioRxiv preprint doi: https://doi.org/10.1101/2021.03.26.437299; this version posted March 28, 2021. The copyright holder for this preprint (which was not certified by peer review) is the author/funder. All rights reserved. No reuse allowed without permission.

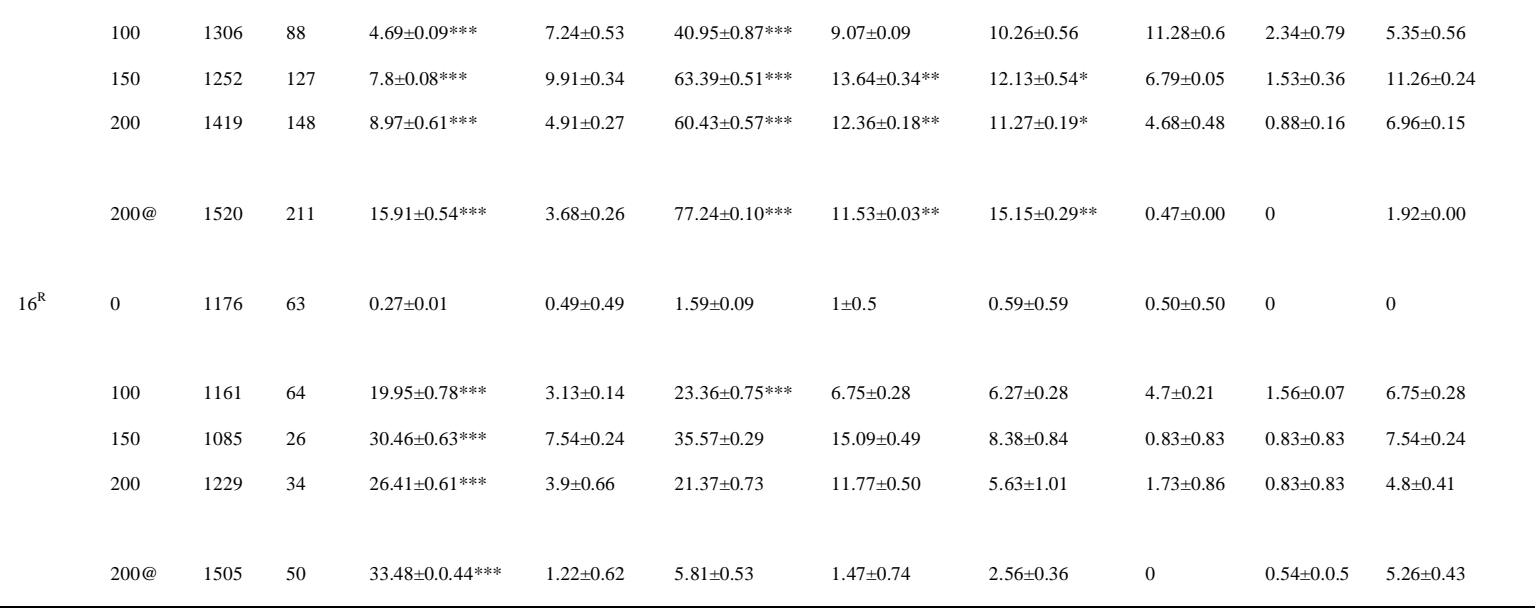

*Significant at $p<0.05, * *$ Significant at $p<0.01, * * *$ Significant at $p<0.001$ as compared to their respective control with $2 \times 2$ contingency $\chi 2$ test with respective $\mathrm{d} f=1$. TC: total cells; TDC: total dividing cells; AC: aberrant cells; Meta: metaphase; Ana: anaphase; Telo: telophase; Cr: Chromosome; Sti: Stickiness. R; Recovery (4 h treatment followed by recovery).

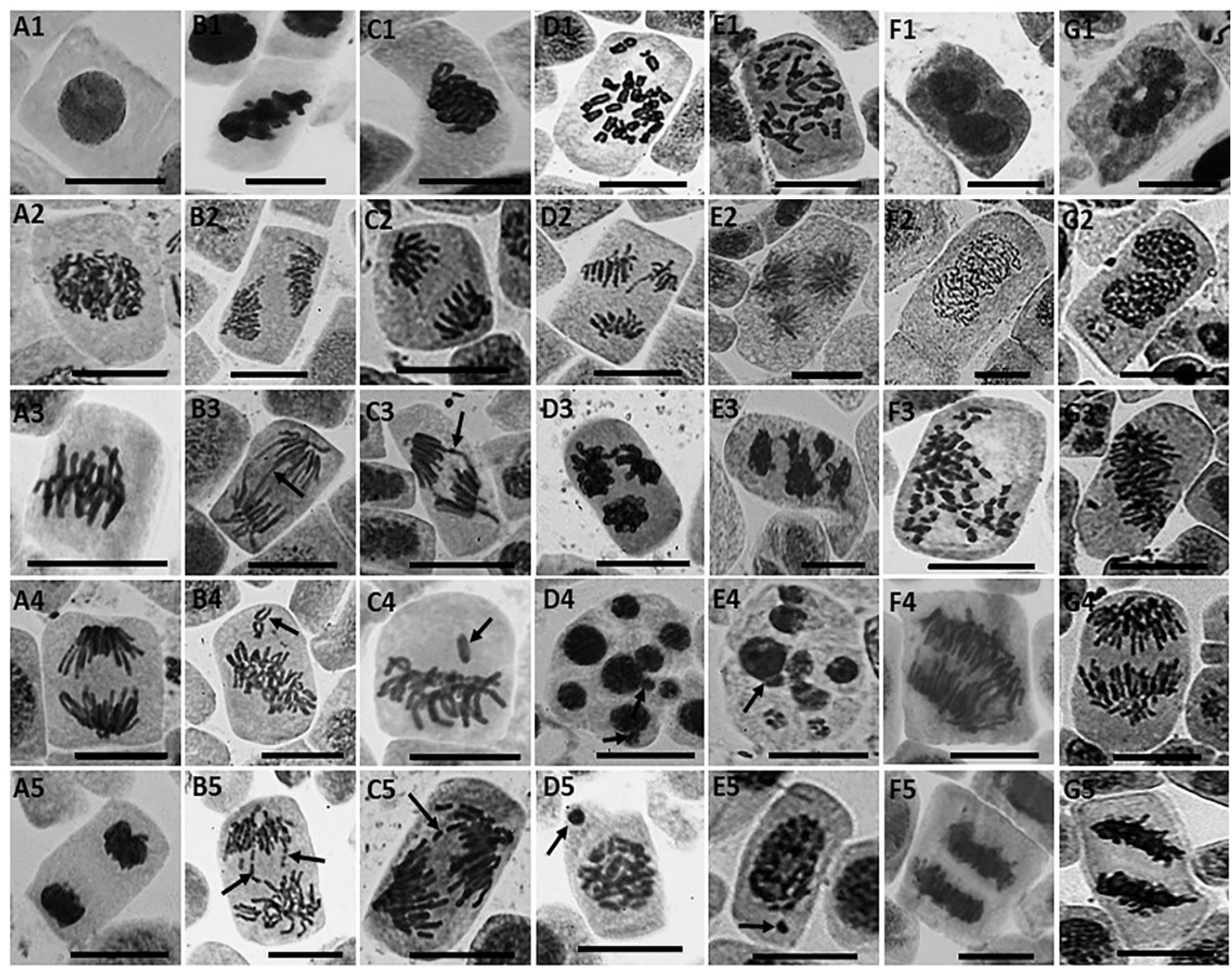

Figure 3. Shows 3-epicaryoptin and colchicine induced formation of different types of CA, MN and $\mathrm{PP}$ cells in A. cepa root apical meristem cells. (A1-A5) control interphase, prophase, metaphase, 
anaphase and telophase; (B1-B5) 3-epicaryoptin induced formation of: (B1) Sticky chromosome at metaphase $\left(150 \mu \mathrm{g} \mathrm{mL}^{-1} / 4 \mathrm{~h}\right.$ ), (B2) Polar deviation at anaphase (100 $\left.\mu \mathrm{g} \mathrm{mL}^{-1} / 16 \mathrm{~h} \mathrm{R}\right)$, (B3) Anaphase bridge $\left(200 \mu \mathrm{g} \mathrm{mL}^{-1} / 2 \mathrm{~h}\right)$, (B4) Vagrant chromosome at metaphase $(100 \mu \mathrm{g} \mathrm{mL}-1 / 4 \mathrm{~h})$, (B5) Lagging chromosome at anaphase $\left(200 \mu \mathrm{g} \mathrm{mL} L^{-1} / 2 \mathrm{~h}\right)$; (C1-C5) $200 \mu \mathrm{g} \mathrm{mL}^{-1}$ colchicine induced formation of: (C1) Sticky chromosome at metaphase (4 h), (C2) polar deviation at anaphase (2 h), (C3) Anaphase bridge (2 h), (C4) Vagrant chromosome at metaphase (16 h R), (C5) Lagging chromosome at anaphase (4 h); (D1-D2) 3-epicaryoptin induced formation of: (D1) C-metaphase (100 $\mu \mathrm{g} \mathrm{mL}^{-1} / 4 \mathrm{~h}$ ), (D2) Multipolar anaphase $\left(200 \mu \mathrm{g} \mathrm{mL}^{-1} / 4 \mathrm{~h}\right)$, (D3) Multipolar telophase $\left(150 \mu \mathrm{g} \mathrm{mL}^{-1} / 2 \mathrm{~h}\right)$ (D4) cells with multiple $\mathrm{MN}$ and nuclear buds $\left(150 \mu \mathrm{g} \mathrm{mL} \mathrm{g}^{-1} / 16 \mathrm{~h} \mathrm{R}\right)$, (D5) $\mathrm{MN}$ at prophase $\left(100 \mu \mathrm{g} \mathrm{mL}^{-1} / 16 \mathrm{~h}\right.$ R); (E1-E5) $200 \mu \mathrm{g} \mathrm{mL}^{-1}$ colchicine induced formation of: (E1) C-metaphase (4 h), (E2) Multipolar anaphase (16 h R), (E3) Multipolar telophase (16 h R), (E4) cells with multiple MN and nuclear buds (16 h R), (E5) MN at prophase (4+16 h); (F1-F5) 3-epicaryoptin induced formation of: (F1) PP interphase $\left(150 \mu \mathrm{g} \mathrm{mL}^{-1} / 4+16 \mathrm{~h}\right)(\mathrm{F} 2) \mathrm{PP}$ prophase $\left(100 \mu \mathrm{g} \mathrm{mL}^{-1} / 16 \mathrm{~h} \mathrm{R}\right.$ (F3) PP metaphase $(100 \mu \mathrm{g}$ $\mathrm{mL}^{-1} / 16 \mathrm{~h} \mathrm{R}$ ), (F4) PP anaphase (200 $\left.\mu \mathrm{g} \mathrm{mL}^{-1} / 16 \mathrm{~h} \mathrm{R}\right)$ and (F5) PP telophase (150 $\left.\mu \mathrm{g} \mathrm{mL}^{-1}\right)$; (G1-G5) $200 \mu \mathrm{g} \mathrm{mL} \mathrm{H}^{-1}$ colchicine induced formation of: (G1) PP interphase (16 h R) (G2) PP prophase (16 h R), (G3) PP metaphase (16 h R), (G4) PP anaphase (16 h R) and (G5) PP telophase (16 h R). R; Recovery (4 $\mathrm{h}$ treatment followed by recovery).

\subsection{Micronuclei and polyploidy}

Both 3-epicaryoptin and colchicine treatments induced the formation of $\mathrm{MN}$ and PP cells in A. cepa root apical meristem (Figure $5 \& 6$ ). A significant increase in the frequency of $\mathrm{MN}$ and PP cells were observed at $4 \mathrm{~h}$ treatment and also at $4 \mathrm{~h}$ treatment followed by $16 \mathrm{~h}$ water recovery. The $\mathrm{MN}$ frequencies were $12.94 \pm 0.34,24.84 \pm 0.54$, and $22.10 \pm 0.73 \%$ respectively for 100,150 , and $200 \mu \mathrm{g} \mathrm{mL}^{-1}$ of 3 -epicaryoptin treated samples after $4 \mathrm{~h}$ treatment followed by $16 \mathrm{~h}(p<0.001)$ recovery. While, $200 \mu \mathrm{g} \mathrm{mL} \mathrm{m}^{-1}$ colchicine showed the highest $\mathrm{MN}$ percentage, $27.73 \pm 0.6 \%$, at $16 \mathrm{~h}(p<0.001)$ recovery treatment (Figure 5). 3-epicaryoptin treatment also statistically increased $(p<0.001)$ the PP cells frequency at $4+16 \mathrm{~h} .150 \mu \mathrm{g} \mathrm{mL}^{-1}$ concentration of 3-epicaryoptin showed $30.61 \pm 0.6 \%$ increased the PP cells frequency. Whereas, the standard colchicine $\left(200 \mu \mathrm{g} \mathrm{mL}^{-1}\right)$ induced $32.66 \pm 0.79 \%$ increase in PP cells frequency (Figure 6). 


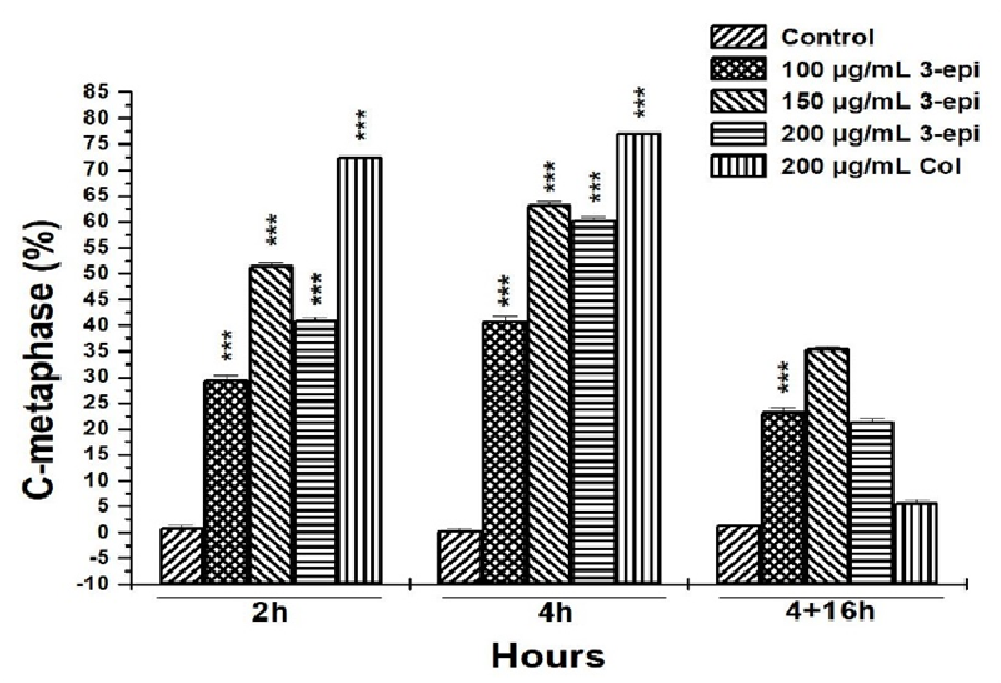

Figure 4: The c-metaphase inducing effect of 3-epicaryoptin and Colchicine on A. cepa root tip cells. ***Significant at $\mathrm{p}<0.001$ with $2 \times 2$ contingency $\chi 2$ analysis compared to respective control at $d f=1$. 3-epi: 3 -epicaryoptin; Col: Colchicine.

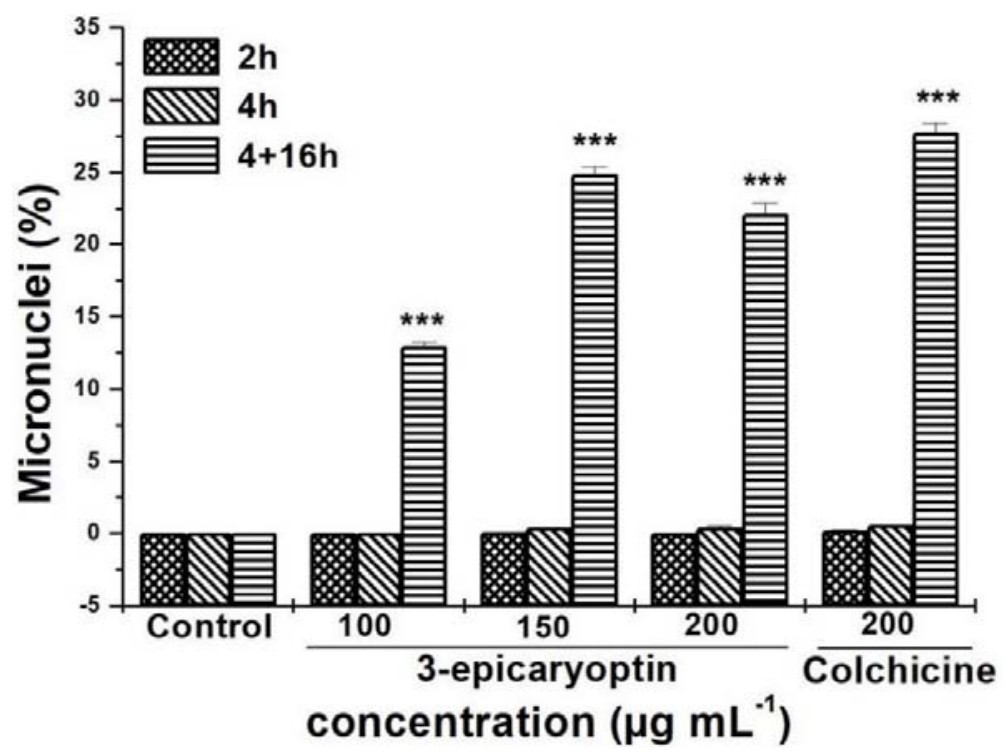

Figure 5: The MN inducing effect of 3-epicaryoptin and Colchicine on A. cepa root tip cells. $* * *$ Significant at $\mathrm{p}<0.001$ with $2 \times 2$ contingency $\chi 2$ analysis compared to respective control at $d f=1$. 


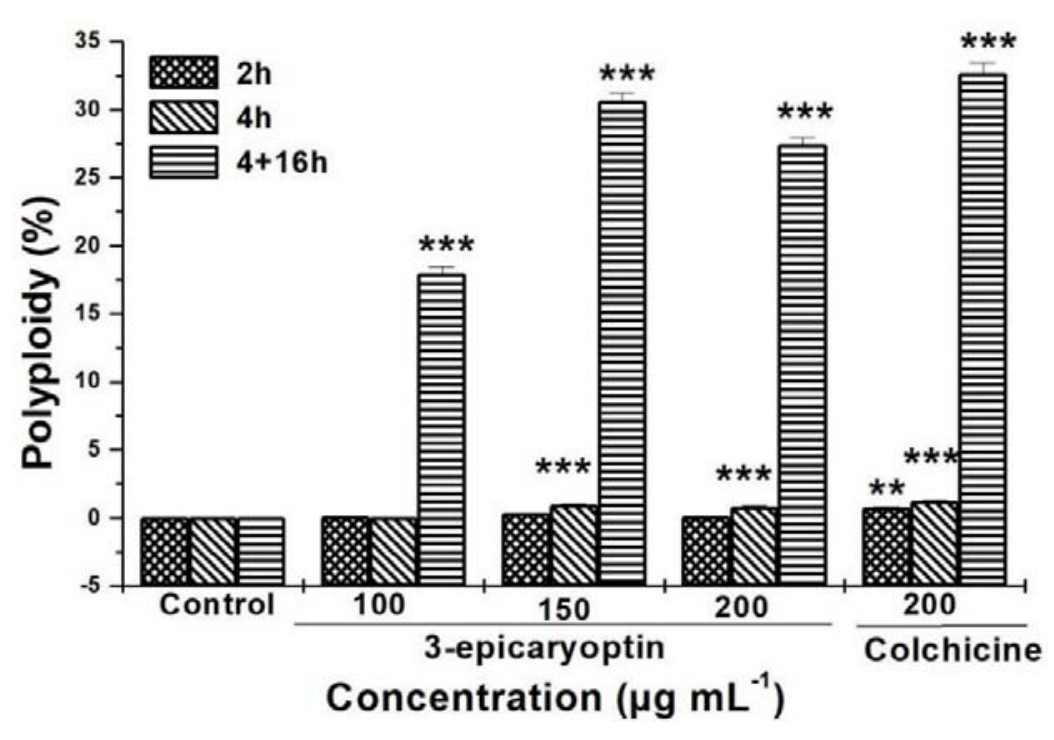

Figure 6: The PP inducing effect of 3-epicaryoptin and Colchicine on A. cepa root tip cells. $* * *$ Significant at $\mathrm{p}<0.001, * *$ Significant at $\mathrm{p}<0.01$ with $2 \times 2$ contingency $\chi 2$ analysis compared to respective control at $d f=1$.

\subsection{Correlation analysis}

Pearson's bivariate correlation analyses were performed to determine positive or negative correlation among dividing phase and with MI. After $4 \mathrm{~h}$ treatment with 3-epicaryoptin, there was a strong positive correlation of metaphase with MI $(r=0.99227)$. However, prophase and anaphase had a strong negative correlation $(r=-0.99422 \&-0.99994)$, with MI, respectively. Prophase and anaphase also showed a strong negative correlation $(r=-0.99986$ $\&-0.99358)$ with metaphase. During $4+16$ h treatment with 3-epicaryoptin, metaphase also showed a strong positive correlation $(r=0.91204)$ with MI and strong negative correlation $(r$ $=-0.9484)$ with prophase. However, anaphase showed a low positive correlation $(r=$ 0.44018) and telophase showed a strong negative correlation $(r=-0.92074)$ with metaphase (Figure 7 \& Table S5). 
Pearson's bivariate correlation analyses was showed that after $4 \mathrm{~h}$ treatment with 3epicaryoptin, there was a strong positive correlation of c-metaphase, vagrant chromosome, MN and PP with aberrant cells (AC) $(r=0.92516,0.85639,0.98442 \& 0.93011)$. Similarly, vagrant, chromosome stickiness, $\mathrm{MN}$ and $\mathrm{PP}$ were strongly correlated with c-metaphase $(r=$ $0.98828,0.93743,0.97748 \& 0.99991$, respectively). There was a positive correlation of chromosome stickiness, MN and PP with vagrant chromosome. Moreover, MN showed a strong positive correlation with PP, respectively. After $4+16 \mathrm{~h}$ treatment with 3 -epicaryoptin, AC showed strong positive correlation with vagrant chromosome, $\mathrm{PP}, \mathrm{MN}$ and anaphase bridge $(r=0.9999,0.98926,0.98553 \& 0.88184)$. While c-metaphase and chromosome stickiness showed moderate positive correlation with AC $(r=0.70739 \& 0.63756)$. However, lagging chromosomes and polar deviation had a strong negative correlation $(r=-0.98594 \&$ 0.92416) with $\mathrm{AC}$ and was found to be similar to that of $4 \mathrm{~h}$ treatment. Vagrant chromosome had showed strong positive correlation ( $r=0.98297 \& 0.98704)$ with MN and PP cells and MN showed similar trends with PP cells $(r=0.99972)$ (Figure7, Table S6).

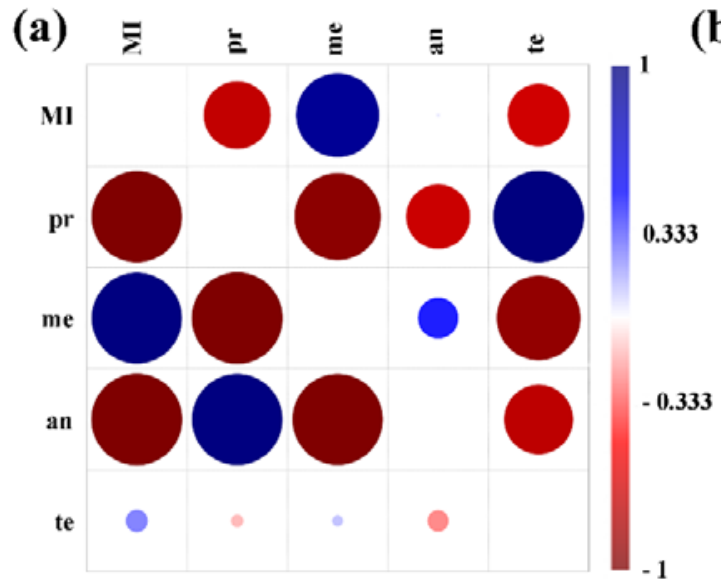

(b)

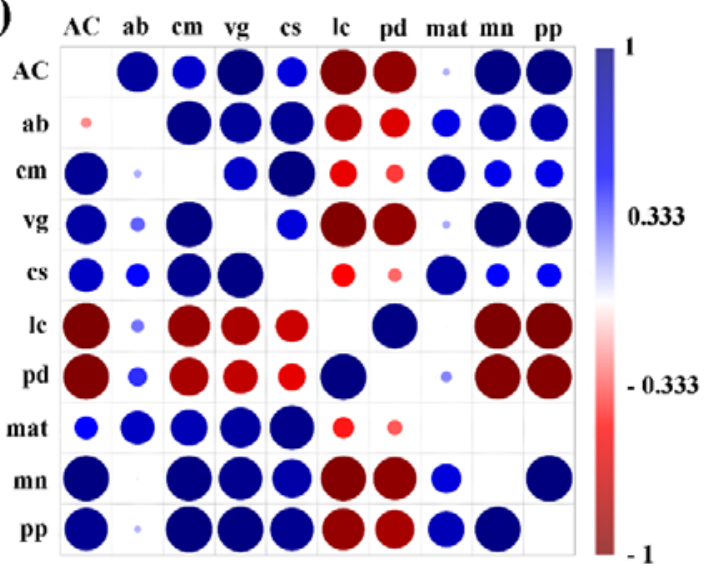

Figure 7. Pearson's correlation analysis for MI, dividing phase (a), and CA (b) after $4 \mathrm{~h}$ and $4+16 \mathrm{~h}$ of water recovery treatment with 3 -epicaryoptin. Here, the lower triangle showed the correlation plot for $4 \mathrm{~h}$ and upper triangle showed the correlation plot for $4+16 \mathrm{~h}$ of treatment. Mitotic index (MI), prophase (pr), metaphase (me), anaphase (an), telophase (te), aberrant cells (AC), anaphase bridge (ab), c-mitosis $(\mathrm{cm})$, vagrant $(\mathrm{vg})$, chromosome stickiness (cs), laggard (lc), polar deviation (pd), multipolar anaphase-telophase (mat), micronucleus (mi), and polyploid cells (po). 


\section{Discussion}

In the present study A. cepa tests system was used for the determination of cell cycle delay and cytotoxic effects of 3-epicaryoptin and was compared with the standard spindle poison compound colchicine. The A. cepa assay has been extremely useful methods for the biological monitoring, investigation of environmental pollution, determination of toxicity as well as evaluation of cytotoxic potentials of various chemical substances (Bakare et al., 2012; Bakare et al., 2013; Bakare et al., 2000; Frescura et al., 2012). Here, the antiproliferative and cell cycle delay inducing activities of 3-epicaryoptin was assessed by observing the root length retardation, swelling, MI\%, and distribution frequencies of the different mitotic phase percentage (prophase, metaphase, anaphase and telophase). In addition, the types of structural CAs as well as MN and PP cells formation were also noted for the determination of aneugenic and/or clastogenic effects. The data exhibited statistically significant $(\mathrm{p}<0.01 \&<$ 0.001) A. cepa root growth retardation effect of 3-epicaryoptin with the $\mathrm{IC}_{50}$ value of $70.5 \mu \mathrm{g}$ $\mathrm{mL}^{-1}$ at $48 \mathrm{~h}$. The $\mathrm{IC}_{50}$ values for the root growth inhibition at $48 \mathrm{~h}$ is considered as reliable for the assessment of cytotoxic effects of tested compounds (Konuk et al., 2007). Generally, the apical meristematic activity is associated to the root growth retardation, to cell elongation and activation of enzymes, which promote the elongation and relaxing of cell wall during differentiation (Fusconi et al., 2006; Webster and MacLeod, 1996). Over $200 \mu \mathrm{g} \mathrm{mL} \mathrm{m}^{-1}$ concentration of 3-epicaryoptin treatment in A. cepa for $4 \mathrm{~h}$ treatment followed by $16 \mathrm{~h}$ recovery $(4+16 \mathrm{~h})$ showed the highest root tip swelling (club shaped) effects and that was similar to that of colchicine effects.

Several study reports showed that growth inhibitory effect of any chemical compound might have been manifested through its cytotoxic effect. Therefore, the present study was further extended to determine the effect of 3-epicaryoptin on the MI\% and division cells percentage

and CA on root meristem cells of A. cepa. 3-epicaryoptin (100, 150, $\left.200 \mu \mathrm{g} \mathrm{mL}^{-1}\right)$ and 
colchicine $\left(200 \mu \mathrm{g} \mathrm{mL}^{-1}\right)$ treatment showed an increased frequency of MI at 2 and $4 \mathrm{~h}$ and again decreased after $16 \mathrm{~h}$ water recovery treatment as compared to control. The observed increased MI\% might be due to arrest the cell cycle in metaphase at 2 and $4 \mathrm{~h}$ and later water recovery treatment for $16 \mathrm{~h}$, cells revert to the interphase condition. The restitution of nuclei that they formed are PP interphase cells. These restitution causes to a fall in the MI\% which was increased due to metaphase arrest during the early hours of treatment by 3-epicaryoptin and colchicine (Davidson et al., 1966). The Pearson's bivariate correlation analysis also indicates a strong positive correlation of increased metaphase with $\mathrm{MI} \%$ at $4 \mathrm{~h}$ treatment. We have also compared the MI and the prophase: metaphase ratio of control, 3-epicaryoptin and colchicine treated samples. In 3-epicaryoptin $\left(150 \mu \mathrm{g} \mathrm{mL}^{-1}\right)$ and colchicine $\left(200 \mu \mathrm{g} \mathrm{mL}^{-1}\right)$ treated roots for $4 \mathrm{~h}$, the mean $\mathrm{MI} \%$ is $12.29 \%$ and $13.18 \%$ respectively and that is significantly $(\mathrm{p}<0.001)$ different from untreated control roots $(5.88 \%)$. Thus, the increased MI\% is significant in the early hours of treatment. On the other hand, prophase: metaphase ratio for 3-epicaryoptin $(150 \mu \mathrm{g} \mathrm{mL}-1)$ is $23.22: 66.20$ and in the case of colchicine $(200 \mu \mathrm{g}$ $\mathrm{mL}^{-1}$ ) treated roots it is 11.3:82.35, whereas the untreated controls showed 42.58:28.84. These indicate an increased number of cells at metaphases in 3-epicaryoptin and colchicine treated roots may be due to as a results of metaphase arrest (Davidson et al., 1966). Besides these metaphase arresting effects, 3-epicaryoptin and colchicine exposure also induced the various CA like anaphase bridges, c-metaphase, vagrant chromosome, sticky chromosomes, c-mitosis, multipolar anaphase-telophase cells in the root tip cells of A. cepa. Study of these chromosome abnormalities has been considered to be a promising test to determine the cytogenotoxic potentials of the applied substances (Caritá and Marin-Morales, 2008). Majority of the observed abnormalities induced by 3-epicaryoptin and colchicine were associated with spindle poisoning effects such as c-metaphase, vagrant and disoriented chromosomes or chromatin dysfunction such as stickiness. Among these CAs, the highest 
types of abnormalities induced by 3-epicaryoptin and colchicine was c-metaphase. It may be mainly occurred due to the irregular distribution of spindle apparatus and or microtubule destabilization effects. It is the spindle poisoning effect of colchicine, showed haphazardly arranged condensed chromosomes at metaphase and therefore blocks the cell progression from metaphase to anaphase (Bonciu et al., 2018; Fiskesjö, 1985). The induction of vagrant chromosomes results of precocious movement of chromosome in spindle poles which leads to an unequal number of chromosomes separation in the daughter nuclei and results the formation of daughter cells with unequal sized nuclei at interphase. The chromosome stickiness is considered to be a chromatid type aberration and its occurrence indicates abnormal DNA condensation, irregular chromosome coiling, chromosome fragmentation and formation of bridges at anapahase-telophase stages, and inactivation of the spindles (Yüzbașioğlu et al., 2003; Badr and Ag, 1987; Klášterská et al., 1976).

In addition to the CAs, cells containing $\mathrm{MN}$ and $\mathrm{PP}$ were also observed at interphase stage in all the treated concentration $\left(100,150 \& 200 \mu \mathrm{g} \mathrm{mL} \mathrm{L}^{-1}\right)$ of 3 -epicaryoptin at $4 \mathrm{~h}$ treatment followed by $16 \mathrm{~h}$ water recovery. Pearson's correlation analysis showed a strong positive correlation of MN with PP. The most effective concentration of 3-epicaryoptin was found to be $150 \mu \mathrm{g} \mathrm{mL}^{-1}$. Such type of MN cells can be originate by chromosomal break and results in the formation of acentric fragments (clastogenic action) or may be due to the loss of entire chromosomes as a consequence of dysfunction in normal spindle apparatus, therefore, was not incorporated with main nucleus during the course of cell division (aneugenic action) and ultimately may leads to the formation of aneuploid and poliploid cells in subsequent mitotic division (Chauhan et al., 1986; Chauhan and Sundararaman, 1990; Fenech and Crott, 2002; Yi and Meng, 2003). 3-epicaryoptin and colchicine induced the formation of such several $\mathrm{MN}$ in the treated cells must probably result from its aneugenic action rather than clastogenic. On the other hand, study of PP cells frequency $(30.61 \pm 0.6, p<0.001)$ formed by 3- 
epicaryoptin treatment $\left(150 \mu \mathrm{g} \mathrm{mL} L^{-1}\right)$ was more or less similar to the colchicine $\left(200 \mu \mathrm{g} \mathrm{mL}^{-1}\right)$ induced PP cells percentage $(32.66 \pm 0.79, p<0.001)$. Levan et al $(1938)$ concluded that the colchicine induced formation of PP cells in A. cepa root tip cells were occurred due to disrupt in the mitotic spindle polymerization, thus prevent the migration of the chromosomes into the poles and remain dispersed throughout the cytoplasm (Levan, 1938). At this stage cytokinesis is not taking place and the chromatids eventually get enclosed with new nuclear membrane and proceed into interphase as a PP cell. Carvalho et al. (2019) also demonstrate that the PP cells arise when the mitotic spindle formation was hindered but the cell cycle was continued and enters into the G1 phase without completing the longitudinal chromosomes segregations, which would normally occur in anaphase and thus became PP (Carvalho et al., 2019). Thus 3epicaryopptin induced increased metaphase (c-metaphase) cells frequency at early hours (2 and $4 \mathrm{~h}$ ) and the formation of MN and PP cells at $16 \mathrm{~h}$ recovery may be due to its colchicine like microtubule destabilization based aneugenic effects.

\section{Conclusions}

The compound 3-epicaryoptin induced cell cycle delay, metaphase arrest, and high frequency of colchicine like metaphase (c-metaphase), MN, and PP cells in A. cepa root tips cells that are may be due to its colchicine like spindle poisoning effects. The 3-epicaryoptin showed a better persistent and effectiveness over cytotoxic actions of colchicine in A. cepa root tip cells; since it has continuously stimulated alterations even at $16 \mathrm{~h}$ water recovery. Therefore, to ascertain its chemotherapeutic applications there is urgent need for further therapeutic benefit and cytotoxic risk assessments using the different standard test systems.

\section{Disclosure statement}

No conflict of interest was declared. 


\section{Acknowledgements}

The authors acknowledge the financial support of CSIR JRF-09/025(0229)/2017-EMR-I

Dated: 26.10.2017, and the DST-PURSE, DST-FIST, UGC-MRP \{F.No.42-563/2013 (SR)

dt. 22.3.13 3 and UGC-DRS-sponsored facilities in the Department of Zoology.

\section{References}

Amirtharaj, R.V., Suresh, V., Kumar, R.S., 2010. Studies on anti-inflammatory and analgesic properties of methanol extract of aerial part of Clerodendrum inerme in experimental animal models. Res. J. Pharmacogn. Phytochem. 2, 421-424.

Anandhi, K., Ushadevi, T., 2013. Analysis of phytochemical constituents and antibacterial activities of Clerodendrum inerme L. against some selected pathogens. Int. J. Biotechnol. Allied Fields 1, 387-393.

Badr, A., Ag, I., 1987. Effect of herbicide glean on mitosis, chromosomes and nucleic acids in Allium cepa and Vicia faba root meristems. Cytologia 52, 293-302.

Bakare, A.A., Adeyemi, A.O., Adeyemi, A., Alabi, O.A., Osibanjo, O., 2012. Cytogenotoxic effects of electronic waste leachate in Allium cepa. Caryologia 65, 94-100.

Bakare, A.A., Alabi, O.A., Gbadebo, A.M., Ogunsuyi, O.I., Alimba, C.G., 2013. In vivo cytogenotoxicity and oxidative stress induced by electronic waste leachate and contaminated well water. Challenges 4, 169-187.

Bakare, A.A., Mosuro, A.A., Osibanjo, O., 2000. Effect of simulated leachate on chromosomes and mitosis in roots of Allium cepa(L.). J. Environ. Biol. 21, 263-271.

Barman, M., Roy, S., Ray, S., 2020. Colchicine Like Metaphase and Cell Cycle Delay Inducing Effects of Leaf Aqueous Extract of Clerodendrum inerme (L.) Gaertn. in Allium cepa Root Apical Meristem Cells. Cytologia 85, 197-201. 
Beninger, C.W., Ndayiragije, P., Arnason, J.T., 1993. Diterpene 3-Epicaryoptin Affects Growth and Development of the European Com Borer (Lepidoptera: Pyralidae). J. Econ. Entomol. 86, 1599-1602.

Bonciu, E., Firbas, P., Fontanetti, C.S., Wusheng, J., Karaismailoğlu, M.C., Liu, D., Menicucci, F., Pesnya, D.S., Popescu, A., Romanovsky, A.V., 2018. An evaluation for the standardization of the Allium cepa test as cytotoxicity and genotoxicity assay. Caryologia 71, 191-209.

Bonfoco, E., Ceccatelli, S., Manzo, L. and Nicotera, P., 1995. Colchicine induces apoptosis in cerebellar granule cells. Exp. Cell Res. 218, 189-200.

Cabrera, G.L., Rodriguez, D.M.G., 1999. Genotoxicity of soil from farmland irrigated with wastewater using three plant bioassays. Mutat. Res. Fund. Mol. Mech. Mut. 426, 211-214.

Caritá, R., Marin-Morales, M.A., 2008. Induction of chromosome aberrations in the Allium cepa test system caused by the exposure of seeds to industrial effluents contaminated with azo dyes. Chemosphere 72, 722-725.

Carvalho, M.S.S., Andrade-Vieira, L.F., dos Santos, F.E., Correa, F.F., das Graças Cardoso, M., Vilela, L.R., 2019. Allelopathic potential and phytochemical screening of ethanolic extracts from five species of Amaranthus spp. in the plant model Lactuca sativa. Sci. Hortic. 245, 90-98.

Chakraborthy, G.S., Verma, P., 2013. Clerodendrum Inerme: A Current Review. Pharmacophore 4, 230-232.

Chaudhuri, A., Ray, S., 2015. Antiproliferative activity of phytochemicals present in aerial parts aqueous extract of Ampelocissus latifolia (Roxb.) planch. on apical meristem cells. Int J Pharm Bio Sci 6, 99-108. 
Chauhan, L.K.S., Dikshith, T.S.S., Sundararaman, V., 1986. Effect of deltamethrin on plant cells I. Cytological effects on the root meristems of Allium cepa. Mutation Research/Genetic Toxicology 171, 25-30.

Chauhan, L.K.S., Sundararaman, V., 1990. Effect of substituted ureas on plant cells II. Ultrastructural effects of isoproturon on the root meristem cells of Allium cepa. Cytologia 55, 99-105.

Chouhan, M.K., Hurkadle, P.J., Hegde, H.V., 2018. Evaluation of Clerodendrum inerme(L.) Gaertn. on Burkitt's Lymphoma Cancer. Indian J. Pharm. Educ. Res. 52, 241-247.

Cragg, G.M., Simon, J.E., Jato, J.G. and Snader, K.M., 1996. Drug discovery and development at the National Cancer Institute: potential for new pharmaceutical crops. Progress in New Crops, ASHS Press, Arlington, VA, pp.554-560.

Davidson, D., MacLeod, R.D., O'Riordan, M., 1966. Changes in mitotic index induced by colchicine. Nature 212, 1541-1542.

Dhooghe, E., Van Laere, K., Eeckhaut, T., Leus, L., Van Huylenbroeck, J., 2011. Mitotic chromosome doubling of plant tissues in vitro. Plant Cell, Tissue and Organ Culture (PCTOC) 104, 359-373.

Fenech, M., Crott, J.W., 2002. Micronuclei, nucleoplasmic bridges and nuclear buds induced in folic acid deficient human lymphocytes-evidence for breakage-fusion-bridge cycles in the cytokinesis-block micronucleus assay. Mutat. Res. Fund. Mol. Mech. Mut. 504, 131-136.

Fiskesjö, G., 1985. The Allium test as a standard in environmental monitoring. Hereditas 102, 99-112.

Frescura, V.D.-S., Laughinghouse Iv, H.D., Tedesco, S.B., 2012. Antiproliferative effect of the tree and medicinal species Luehea divaricata on the Allium cepa cell cycle. Caryologia 65, 27-33. 
Fusconi, A., Repetto, O., Bona, E., Massa, N., Gallo, C., Dumas-Gaudot, E., Berta, G., 2006. Effects of cadmium on meristem activity and nucleus ploidy in roots of Pisum sativum L. cv. Frisson seedlings. Environ. Exp. Bot. 58, 253-260.

George, M., Pandalai, K.M., 1949. Investigations on Plant Antibiotics. Part IV. Further Search for Antibiotic Substances in Indian Medicinal Plants. Indian. J. Med. Res. 37, 169-181.

Gomes, K.M.S., Oliveira, M.V.G.A.d., Carvalho, F.R.d.S., Menezes, C.C., Peron, A.P., 2013. Citotoxicity of food dyes sunset yellow (E-110), bordeaux red (E-123), and tatrazine yellow (E-102) on Allium cepa L. root meristematic cells. Food Sci. Technol. 33, 218-223.

Govindachari, T.R., Suresh, G., Gopalakrishan, G., Wesley, S.D., Singh, N.D.P., 1999. Antifeedant activity of some diterpenoids. Fitoterapia 70, 269-274.

Hosozawa, S., Kato, N., Munakata, K., 1974. Diterpenoids from Clerodendron calamitosum. Phytochemistry.

Kalavathi, R., Sagayagiri, R., 2016. Anticancer Activity of Ethanolic Leaf Extract of Clerodendrum inerme Against Lung Adenocarcinoma Epithelial Cell Line. Eur. J. Mol. Biol. Biochem. 3, 69-72.

Kalyanasundaram, M., Das, P.K., 1985. Larvicidal and synergistic activity of plant extracts for mosquito control. Indian J. Med. Res. 82, 19-23.

Khanam, D., Deb, D., Dev, S., Shahriar, M., Das, A.K., Kawsar, M.H., 2014. Analgesic and Anti-inflammatory Activities of Ethanolic Extract of Clerodendrum inerme (L.) Gaertn. Bangladesh J. Pharmacol. 17, 62-66.

Kirtikar, K.R., Basu, B.D., 1975. Clerodendron inerme (L) Gaertn. Indian Medicinal Plants. Allahabad, India: Lalif Mohan Basu, 1945-1947. 
Klášterská, I., Natarajan, A.T., Ramel, C., 1976. An interpretation of the origin of subchromatid aberrations and chromosome stickiness as a category of chromatid aberrations. Hereditas 83, 153-162.

Konuk, M., Liman, R., Cigerci, I.H., 2007. Determination of genotoxic effect of boron on Allium cepa root meristematic cells. Pak. J. Bot. 39, 73.

Kundu, L.M., Ray, S., 2017. Mitotic abnormalities and micronuclei inducing potentials of colchicine and leaf aqueous extracts of Clerodendrum viscosum Vent. in Allium cepa root apical meristem cells. Caryologia 70, 7-14.

Leme, D.M., Marin-Morales, M.A., 2009. Allium cepa test in environmental monitoring: a review on its application. Mutat. Res. Rev. Mutat. Res. 682, 71-81.

Levan, A., 1938. The effect of colchicine on root mitoses in Allium. Hereditas 24, 471-486.

Li, R., Morris-Natschke, S.L., Lee, K.-H., 2016. Clerodane diterpenes: sources, structures, and biological activities. Nat. Prod. Rep. 33, 1166-1226.

Manoharan, S., Kavitha, K., Senthil, N., Renju, G.L., 2006. Evaluation of anticarcinogenic effects of Clerodendron inerme on 7, 12-dimethylbenz (a) anthracene-induced hamster buccal pouch carcinogenesis. Singapore Med. J. 47, 1038-1043.

Mehdi, H., Tan, G.T., Pezzuto, J.M., Fong, H.H.S., Farnsworth, N.R., El-Feraly, F.S., AlYahya, M.A., Mossa, J.S., Peeples, M.E., Kernan, M.R., 1997. Cell culture assay system for the evaluation of natural product-mediated anti-Hepatitis B virus activity. Phytomedicine 3, 369-377.

Mouri, A., Lee, H.J., Mamiya, T., Aoyama, Y., Matsumoto, Y., Kubota, H., Huang, W.J., Chiou, L.C., Nabeshima, T., 2020. Hispidulin attenuates the social withdrawal in isolated disrupted $\square$ in $\square$ schizophrenia $\square 1$ mutant and chronic phencyclidine $\square$ treated mice. Br. J. Pharmacol. 177, 3210-3224. 
Muthu, C., Ayyanar, M., Raja, N., Ignacimuthu, S., 2006. Medicinal plants used by traditional healers in Kancheepuram District of Tamil Nadu, India. J. Ethnobiol. Ethnomedicine 2, 1-10.

Negi, A.S., Gautam, Y., Alam, S., Chanda, D., Luqman, S., Sarkar, J., Khan, F., Konwar, R., 2015. Natural antitubulin agents: Importance of 3, 4, 5-trimethoxyphenyl fragment. Bioorg. Med. Chem. 23, 373-389.

Pereira, J., Gurudutt, K.N., 1990. Growth inhibition of Musca domestica L. and Culex quinquefasciatus (say) by (-)-3-epicaryoptin isolated from leaves of Clerodendron inerme (Gaertn)(Verbenaceae). J. Chem. Ecol 16, 2297-2306.

Prasad, M.P., Sushant, S. and Chikkaswamy, B.K., 2012. Phytochemical analysis, antioxidant potential, antibacterial activity and molecular characterization of Clerodendrum species. Int. J. Mol. Biol. 3, 71-76.

Rajeev, P., Kumar, Y.S., Gupta, S.K., 2012. Anti-diabetic activity of Clerodendrum (or Clerodendron) inerme using in vivo and in vitro studies, novel science. Int J Pharm Sci 1, 298-302.

Ray Sanjib, B.M., Roy Sujit, 2019. Liquid-liquid fractionation mediated extraction and purification process of 3-epicaryoptin, in: Office, I.P. (Ed.), Official journal of the patent office, India, p. 20622.

Ray, S., Kundu, L.M., Goswami, S., Roy, G.C., Chatterjee, S., Dutta, S., Chaudhuri, A., Chakrabarti, C.S., 2013. Metaphase arrest and delay in cell cycle kinetics of root apical meristems and mouse bone marrow cells treated with leaf aqueous extract of Clerodendrum viscosum Vent. Cell Prolif. 46, 109-117.

Roy, S., Kundu, L.M., Roy, G.C., Barman, M., Chakraborty, T., Ghosh, P., Das, R., Tripathy, D., Singh, N., Banerjee, S., Bhattacharjee, A., Pal, A., Chatterjee, A., Ray, S., 2020a. Deciphering colchicine like actions of clerodin in terms of microtubule 
destabilization based mitotic abnormalities, G2/M-phase arrest, and plant polyploidy. bioRxiv, 2020.2012.2027.424481.

Roy, S., Kundu, L.M., Roy, G.C., Barman, M., Ray, S., 2020b. Pro-metaphase arrest, polyploidy, micronuclei, and mitotic abnormality inducing agents' isolation from leaf aqueous extract of \&lt;em\&gt;Clerodendrum viscosum\&lt;/em\&gt; Vent. bioRxiv, 2020.2011.2029.402370.

Salmon, E.D., McKeel, M., Hays, T., 1984. Rapid rate of tubulin dissociation from microtubules in the mitotic spindle in vivo measured by blocking polymerization with colchicine. The Journal of cell biology 99, 1066-1075.

Sehgal, R., Roy, S. and Kumar, V.L., 2006. Evaluation of cytotoxic potential of latex of Calotropis procera and Podophyllotoxin in Allum cepa root model. Biocell. 30, 9.

Sharma, W., Verma, H.W., 1991. Antifungal activity of Clerodendrum sp. on fungal rotting fungi. Fitoterapia 62, 517-518.

Tanu, G.M., Aggarwal, S. and Kumar, A., 2011. Pharmacognostic and phytochemical evaluation of Clerodendron inerme. The Pharma Research 5, 116-121.

Thirumal, M., Srimanthula, S., Kishore, G., Vadivelan, R., Anand Kumar, A.V.S., 2013. Analgesic and antipyretic effects of aqueous extract from Clerodendrum inerme (L.) Gaertn. leaves in animal models. Der Pharm. Lett. 5, 315-323.

Webster, P.L., MacLeod, R.D., 1996. The root apical meristems and its margins. Plant roots. The hidden half. Marcel Dekker Inc, New York, 51-76.

Yi, H., Meng, Z., 2003. Genotoxicity of hydrated sulfur dioxide on root tips of Allium sativum and Vicia faba. Mutat. Res. Genet. Toxicol. Environ. Mutagen. 537, 109114. 
bioRxiv preprint doi: https://doi.org/10.1101/2021.03.26.437299; this version posted March 28, 2021. The copyright holder for this preprint (which was not certified by peer review) is the author/funder. All rights reserved. No reuse allowed without permission.

Yüzbaşioğlu, D., Ünal, F., Sancak, C., Kasap, R., 2003. Cytological effects of the herbicide racer "flurochloridone" on Allium cepa. Caryologia 56, 97-105. 